\title{
Dysfunkce chlopenní náhrady
}

50letá obézní hypertonička s ischemickou chorobou srdeční prodělala $\mathrm{v}$ roce 2002 srdeční revaskularizaci trojitým bypassem; současně jí byla pro významnou mitrální insuficienci implantována náhrada - mechanická protéza Medtronic Hall (Minneapolis, MN, USA) - do mitrální pozice. Po operaci byla pacientka dlouhodobě bez anginy pectoris, avšak $\mathrm{s}$ projevy městnavého srdečního selhávání NYHA III. Byla pravidelně echokardiograficky sledována (naposledy v únoru 2005) s nálezem systolické dysfunkce levé komory s ejekční frakcí $30 \%$ při difuzní hypokinezi a $\mathrm{s}$ dobrou funkcí náhrady regurgitace 1. stupně, maximální gradient $10 \mathrm{~mm} \mathrm{Hg}$.

V květnu 2005 byla pacientka přijata na interní oddělení pro týdenní anamnézu zhoršujicích se projevů levostranného srdečního selhání. Po 48 hodinách hospitalizace dochází i pres adekvátní léčbu $\mathrm{k}$ progresi srdečního selhání do obrazu plicního otoku. Ve fyzikálním nálezu bylo prítomno (vedle běžných známek akutního srdečního selhání) i oslabení otevíra-

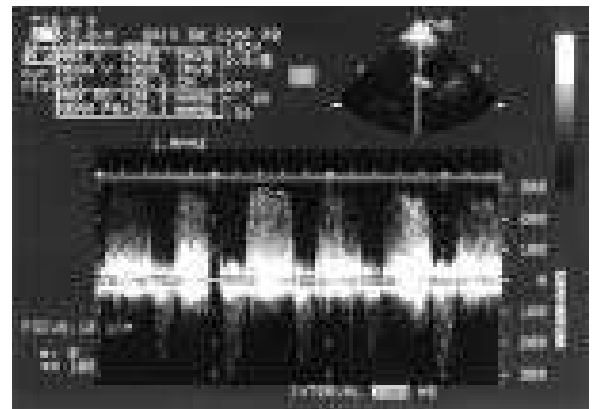

Obr. 1 Transthorakální echokardiografický nález významného gradientu na chlopenní náhradě

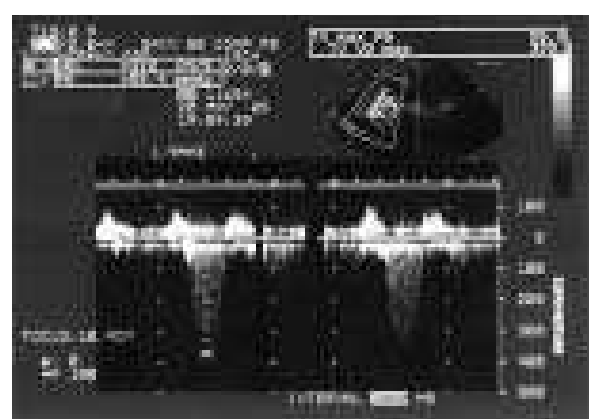

Obr. 2 Transthorakální echokardiografický nález regurgitace na trikuspidální chlopni při významné plicní hypertenzi

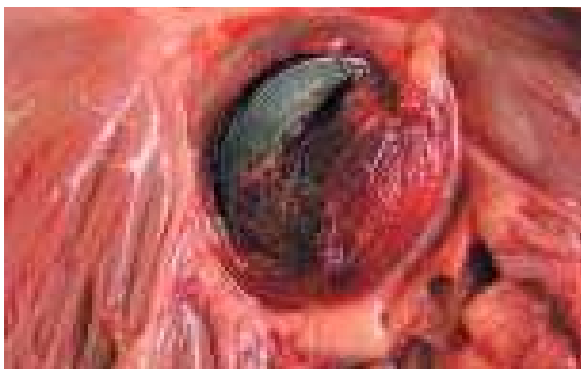

Obr. 3 Sekční nález obturované chlopenní náhrady $z$ pohledu $z$ levé komory

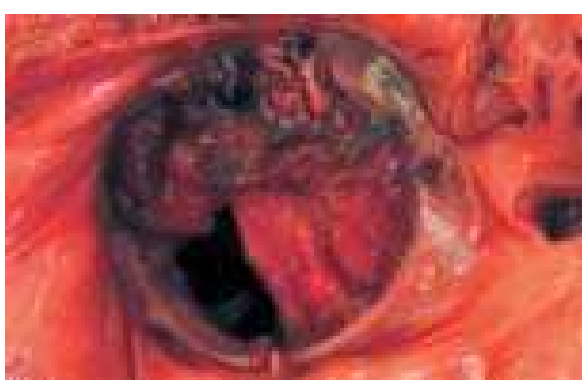

Obr. 4 Sekční nález obturované chlopenní náhrady $z$ pohledu $z$ levé síně

cîho kliku mitrální náhrady a slabý diastolický šelest na srdečním hrotu. Po stabilizaci stavu intenzifikovanou léčbou srdečního selhání - i. v. furosemidem, i. v. nitroglycerinem a levosimendanem byla pacientka echokardiograficky vyšetřena. Byl prítomen nález významné stenózy na chlopenní protéze (PG max. 34 mm Hg, MPG 28 mm Hg, MVA 0,49 cm²) bez regurgitace, přes špatnou morfologickou přehlednost chlopně byla patrna omezená hybnost disku protézy, celá oblast chlopenní náhrady byla výraznè hyperechogenní (obrázek 1). Zároveň byla přítomna významná trikuspidálnî insuficience se známkami těžké plicní hypertenze (obrázek 2) a významná dysfunkce levé i pravé komory. Bylo kontaktováno kardiochirurgické centrum, ale vzhledem ke špatnému klinickému stavu a významné dysfunkci levé komory nebylo operační řešení indikováno. Trombolýza nemohla být podána vzhledem $\mathrm{k}$ hypokoagulačnímu stavu - při přijetí bylo INR nad 5 .

Další průběh nemoci byl nepřiznivý, pacientka umírá za 36 hodin od prrijetí na koronární jednotku pod obrazem nezvladatelného srdečního selhání s kardiogenním šokem.

Na sekci byla potvrzena obstrukce chlopenní protézy pannem vrůstajícím pod chlopeň ze síñové strany, na komorové straně byl přitomen již částečně organizovaný trombus (obrázky 3,4). Trombóza chlopenní náhrady je vzácná komplikace $\mathrm{s}$ výskytem $0,1-0,5 \%{ }^{(1,2)}$ na rok života s chlopní; jde vždy o stav závažný s vysokou mortalitou. Vyskytuje se asi 2 krát častěji na mitrální náhradě než na aortální. ${ }^{(1)}$ Obstrukce chlopenního ústí bývá způsobena trombem nebo pannem (přerůstání tkání $\mathrm{z}$ našívacího prstence do chlopenního ústí)..$^{(1-3)}$ Na obstrukci trombem ukazuje rychlý vznik, nedostatečná koncentrace antikoagulace a projevy systémové embolizace, pro pannus je typický pomalý vývoj a vznik delší dobu po operaci. ${ }^{(4)}$ V echokardiografickém obraze bývá pannus hyperechogenní, na rozdíl od trombu. ${ }^{(4)}$ Může se vyskytnout trombus nasedající na pannus. ${ }^{(1)}$

Léčebné možnosti zahrnují chirurgickou lečbu, trombolýzu, nebo augmentaci antiakoagulační léčby. ${ }^{(3)} \mathrm{K}$ chirurgickému řešení bývají indikováni pacienti $\mathrm{v}$ dobrém klinickém stavu za předpokladu, že jde o pannus nebo o nález velkého vlajícího trombu. (1) Trombolýza je vhodná $\mathrm{u}$ nemocných $\mathrm{s}$ vysokým operačním rizikem (NYHA IV a s významnými komorbiditami) s prredpokladem čerstvého trombu. ${ }^{(1,3)}$

Operační mortalita se pohybuje kolem $10 \%$ u pacientů stabilních (NYHA I-III), u pacientů v závažném stavu (NYHA IV) kolísá od 15-45 \%. ${ }^{(1,3,5,6)}$ Operace pro pannus jsou spojeny s nižší mortalitou než pro trombus. Mortalita trombolýzy se pohybuje kolem $10 \%$, její neúspěšnost pak mezi 10-15\%, riziko retrombózy je vysoké. ${ }^{(1,3,5,6)} \mathrm{U}$ pacientů $\mathrm{s}$ malým trombem, klinicky stabilních (NYHA I-II), je možné se pokusit o zvládnutí stavu při zesílení antikoagulační léčby.

\section{LITERATURA}

1. Dominik J, Veselka J. Komplikace u nemocných s chlopenní náhradou. V: Aschermann M. Kardiologie. Praha: Galén, 2004:1319-21.

2. Braunwald E. Valvular Heart Disease. In: Braunwald E, Zipes D, Libby P. Heart Disease: a textbook of cardiovascular medicine. Philadelphia, London, New York, St. Louis, Sydney, Toronto: W. B. Sounders Company, 2001:1697-9.

3. Bonow R, et al. ACC/AHA Guidelines for the management of patients with valvular heart disease. JACC 1998;32:1486-588.

\section{Jan Mrózek, Vladimír Srp, Ivo Horák}

II. interní oddělení-kardiovaskulární, Městská nemocnice Ostrava, Ostrava, Česká republika

Adresa: MUDr. Jan Mrózek, II. interní oddělení-kardiovaskulární, Městská nemocnice, Nemocniční 20, 70200 Ostrava, Česká republika, e-mail: honzamrozek@email.cz 